\title{
An Improved Matlab-Simulink Model of PV Module considering Ambient Conditions
}

\author{
R. Ayaz, I. Nakir, and M. Tanrioven \\ Department of Electrical Engineering, Yildiz Technical University, Davutpasa Campus, 34220 Istanbul, Turkey \\ Correspondence should be addressed to R. Ayaz; ayaz@yildiz.edu.tr
}

Received 6 March 2014; Accepted 6 August 2014; Published 24 August 2014

Academic Editor: Serap Gunes

Copyright (c) 2014 R. Ayaz et al. This is an open access article distributed under the Creative Commons Attribution License, which permits unrestricted use, distribution, and reproduction in any medium, provided the original work is properly cited.

\begin{abstract}
A photovoltaic (PV) model is proposed on Matlab/Simulink environment considering the real atmospheric conditions and this PV model is tested with different PV panels technologies (monocrystalline silicon, polycrystalline silicon, and thin film). The meteorological data of Istanbul-the location of the study — such as irradiance, cell temperature, and wind speed are taken into account in the proposed model for each technology. Eventually, the power outputs of the PV module under real atmospheric conditions are measured for resistive loading and these powers are compared with the results of proposed PV model. As a result of the comparison, it is shown that the proposed model is more compatible for monocrystal silicon and thin-film modules; however, it does not show a good correlation with polycrystalline silicon PV module.
\end{abstract}

\section{Introduction}

Solar energy is one of the most important renewable energy sources because it is being environmentally friendly, sustainable, and fuel cost-free. Therefore, studies and applications related to PV systems are increasing continuously.

PV modules are semiconductor structures that convert solar energy into electrical energy. PV systems have been used in many applications such as satellite systems, communication systems, water pumps, electric vehicle applications, and solar power plants. The two most important factors determining energy outputs of PV are radiation and cell temperature. PV cell performances given in the datasheets are defined under standard test conditions (radiation $1000 \mathrm{~W} / \mathrm{m}^{2}$ and the temperature $25^{\circ} \mathrm{C}$ ) [1]. On the other hand, it is necessary to know the characteristics of PV panels for different environmental conditions since they face unusually altering conditions when they are used in real environment.

Many different studies have been conducted in the literature to obtain PV model [1-8] that include single-diode model [1-3] and double-diode model [9]. Although doublediode model has the most accurate results; it includes too many parameters and complex expressions [9]. It has been observed that single-diode model also gave accurate results in many studies $[10,11]$. In a majority of these models catalog values are compared with experimental results by taking into account different environmental conditions [8, 12-14].

In this paper, single-diode model is used to develop an enhanced model in Simulink which takes irradiance, cell temperature, and wind speed values into consideration simultaneously. The presented model was applied on three different PV technologies (monocrystalline, polycrystalline, and thin film) individually while supplying a certain resistive load and compared with experimentally obtained PV panel values. This paper is organized as follows. Mathematical expressions and proposed model are presented in Section 2. Section 3 presents the experimental setup designed to measure the actual ambient conditions and power output of PV panels. The obtained results are presented and discussed in Section 4 and conclusion is given in Section 5.

\section{Numerical Background and Modeling}

Reference [2] was used as a basis for the model proposed in this study. Simplified equivalent circuit model used in the PV model is shown in Figure 1. In this model, PV current is calculated as a function of voltage. The model was carried out by using only PV panel's datasheet values. In the proposed model, input parameters are irradiance, cell temperature, and 


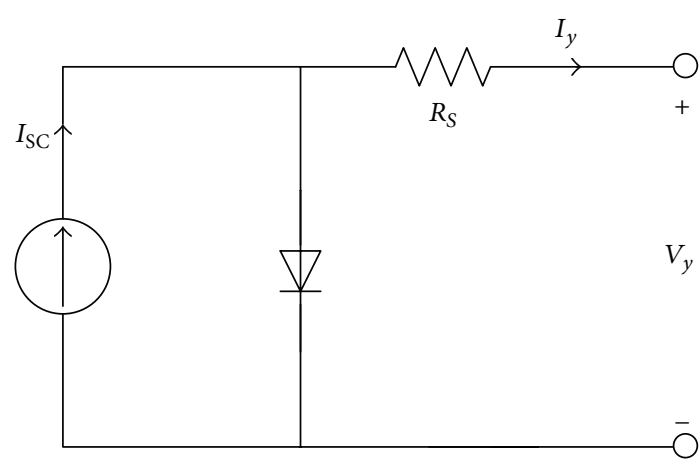

FIgURE 1: Simplified equivalent circuit model.

wind speed and the output parameters are the PV current, PV voltage, and $\mathrm{PV}$ power.

PV cell output current $\left(I_{y}\right)$ is a function of PV output voltage $\left(V_{y}\right)$. PV modules are modeled using the following mathematical equations [2]:

$$
I_{y}=I_{\mathrm{SC}} \cdot\left[1-K_{1} \cdot\left(e^{\left(V_{y} /\left(K_{2} \cdot V_{\mathrm{OC}}\right)\right)}-1\right)\right] \text {, }
$$

where

$$
\begin{gathered}
K_{1}=\left(1-\frac{I_{\mathrm{MP}}}{I_{\mathrm{SC}}}\right) \cdot e^{\left(-V_{\mathrm{MP}} /\left(K_{2} \cdot V_{\mathrm{OC}}\right)\right)}, \\
K_{2}=\frac{\left(\left(V_{\mathrm{MP}} / V_{\mathrm{OC}}\right)-1\right)}{\ln \left(1-\left(I_{\mathrm{MP}} / I_{\mathrm{SC}}\right)\right)} .
\end{gathered}
$$

It is seen from (2) that $K_{1}$ and $K_{2}$ coefficient change according to different PV panel parameters. Variation of these parameters according to the irradiance and/or cell temperature is given below [2]:

$$
\begin{gathered}
I_{\mathrm{SC}}\left(G, T_{C}\right)=I_{\mathrm{SCS}} \cdot \frac{G}{G_{S}} \cdot\left[1+\alpha \cdot\left(T_{\mathrm{C}}-T_{S}\right)\right], \\
I_{\mathrm{MP}}\left(G, T_{C}\right)=I_{\mathrm{MPS}} \cdot \frac{G}{G_{S}} \cdot\left[1+\alpha \cdot\left(T_{C}-T_{S}\right)\right], \\
V_{\mathrm{OC}}\left(T_{C}\right)=V_{\mathrm{OCS}}+\beta \cdot\left(T_{C}-T_{S}\right), \\
V_{\mathrm{MP}}\left(T_{C}\right)=V_{\mathrm{MPS}}+\beta \cdot\left(T_{\mathrm{C}}-T_{S}\right) .
\end{gathered}
$$

The parameters $I_{\mathrm{SCS}}, I_{\mathrm{MPS}}, V_{\mathrm{OCS}}$, and $V_{\mathrm{MPS}}$ are the values given in the manufacturer's catalog and defined for the standard test conditions $\left(G_{S}=1000 \mathrm{~W} / \mathrm{m}^{2}\right.$ and $\left.T_{S}=25^{\circ} \mathrm{C}\right) . G$ and $T_{C}$ represent the radiation and cell temperature, respectively. $\alpha$ and $\beta$ show the current temperature coefficient and voltage temperature coefficient, respectively.

PV cell temperature is considered as equal to the ambient temperature in some studies in the literature, which is not the actual case in every situation. In this study, the PV cell temperature is calculated as a function of the ambient temperature and irradiance variation [15]:

$$
T_{C}=1.14 \cdot\left(T-T_{S}\right)+0.0175 \cdot(G-300)+30 .
$$

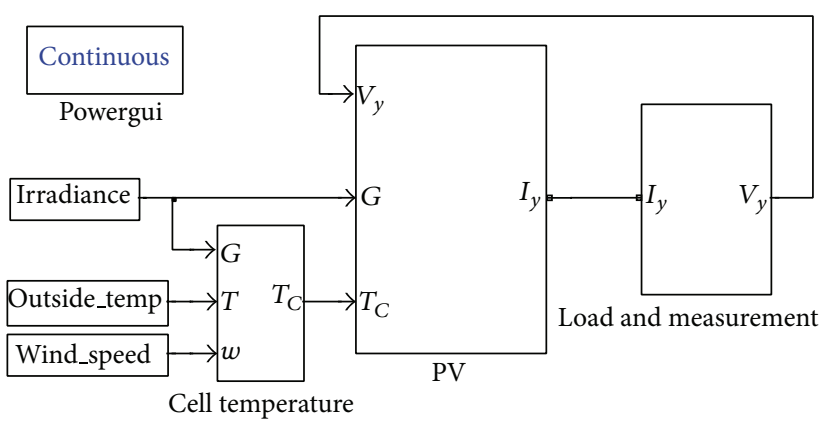

Figure 2: The Matlab/Simulink block diagram of PV model.

In addition, wind speed has also effect on PV cell temperature and this effect is taken into account separately for calculating the PV cell temperature for each module:

$$
\begin{aligned}
T_{C}= & 1.14 \cdot\left(T-T_{S}\right)+0.0175 \cdot(G-300) \\
& -k_{r} \cdot w+30 .
\end{aligned}
$$

The coefficient $k_{r}$ varies for each PV technology. In this study, $k_{r}$ is taken as 1.509 for monocrystalline, as 1.468 for polycrystalline, and as 1.450 for thin-film technology [16]. The Simulink block diagram related to proposed PV model is given in Figure 2 .

The cell temperature block involved in the Simulink scheme of PV model is for calculation of cell temperature by considering radiation, ambient temperature, and the wind speed as in (5). Load \& Measurement block is engaged for measurement of PV panel load current and PV panel load voltage. The block diagram of PV panel subsystem is shown in Figure 3.

The model given in Figure 3 is obtained from (1)-(3). The cell parameters block in the block diagram uses $I_{\mathrm{SC}}, I_{\mathrm{MP}}, V_{\mathrm{OC}}$, and $V_{\mathrm{MP}}$ values obtained in the standard test conditions to determine actual values of these parameters depending on the cell temperature and radiation. The Cell Current block, which also takes place in the block diagram, calculates PV current by utilizing (1).

\section{Experimental Setup and Methodology}

In this study, the obtained results from PV model were compared with the experimental results to show the accuracy of the PV model. The current and voltage values of PV panels were measured at ambient conditions for three different PV technologies. PV panels were combined together on a platform as shown in Figure 4 and the platform is mounted with $41^{\circ}$ angle on the roof of faculty building.

The datasheet parameters of PV panels used in the study are given in Table 1.

A pyranometer located with tilt angle of platform $\left(41^{\circ}\right)$ was used to measure the incident global radiation on the surface of PV panels. The measurement setup is shown in Figure 5.

A weather station is used to measure outdoor temperature and wind speed data to be used as input parameters to 
TABLE 1: Characteristic parameters of PV panels.

\begin{tabular}{lccc}
\hline Technology & Monocrystalline & Thin film & Polycrystalline \\
\hline Peak power $(\mathrm{W})$ & 50 & 55 & 60 \\
Short circuit current $\left(I_{\mathrm{SC}}\right)(\mathrm{A})$ & 3.14 & 1.57 & 3.97 \\
Open circuit voltage $\left(V_{\mathrm{OC}}\right)(\mathrm{V})$ & 21.4 & 61.44 & 21.70 \\
Maximum power current $\left(I_{\mathrm{MP}}\right)(\mathrm{A})$ & 2.88 & 1.21 & 3.41 \\
Maximum power voltage $\left(V_{\mathrm{MP}}\right)(\mathrm{V})$ & 17.4 & 45.45 & 17.60 \\
\hline
\end{tabular}

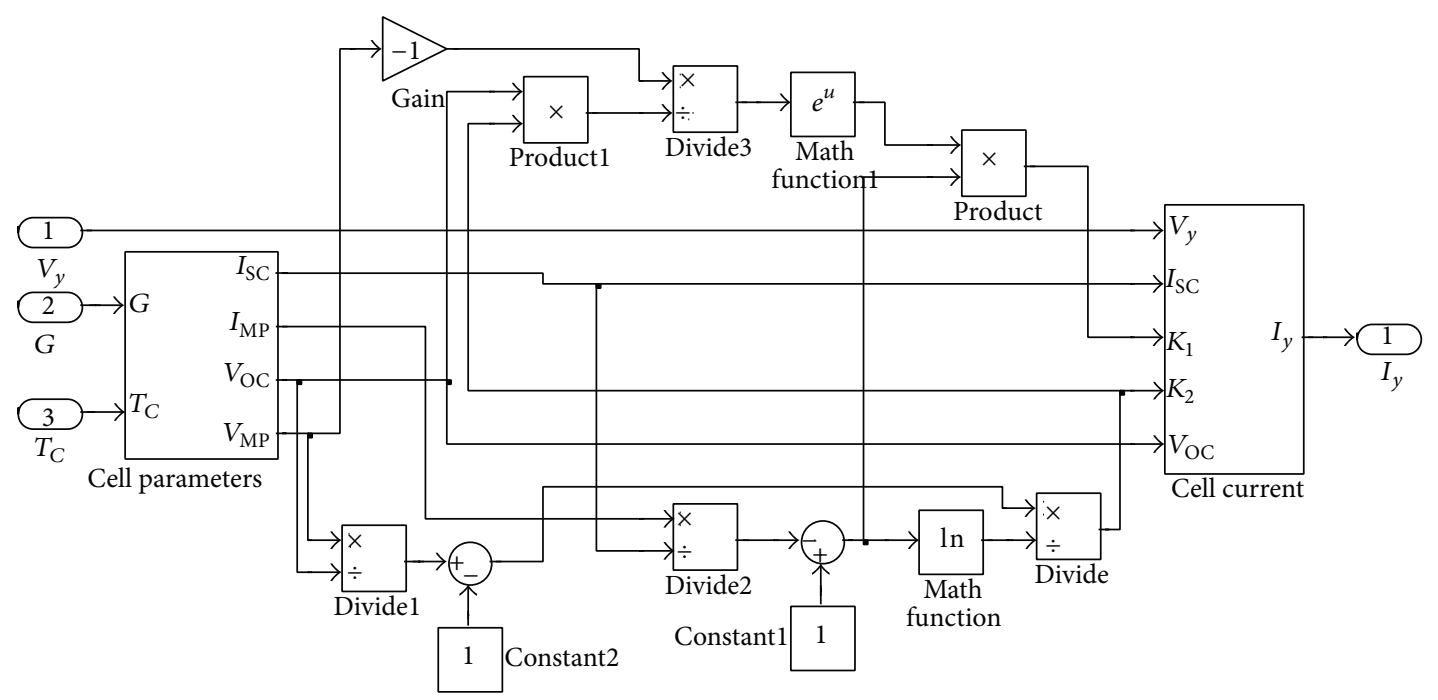

Figure 3: PV panel subsystem block diagram.

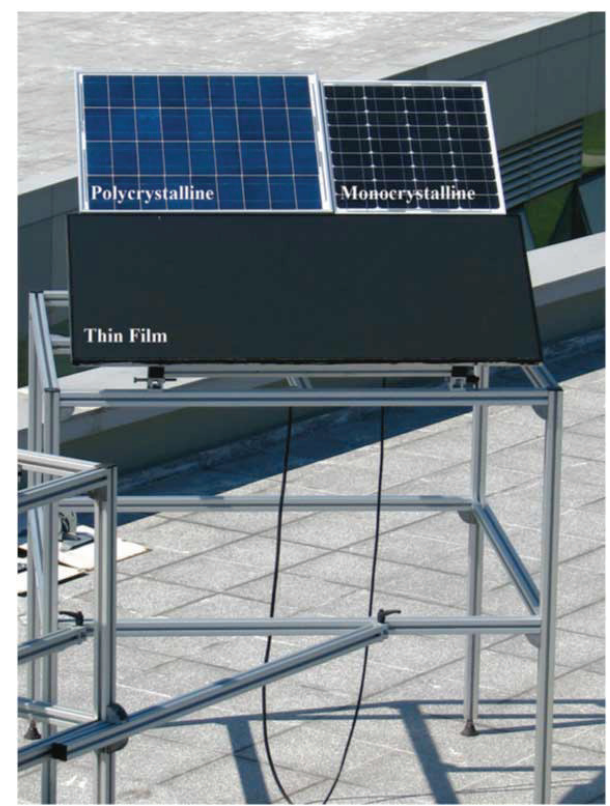

FIgURE 4: The platform with three different PV panel technologies positioned with $41^{\circ}$ tilt angle.

the model. A schematic representation of PV model input parameters and current and voltage measurements of three different panels are given in Figure 6.

Each panel output is connected to the resistive loads with different values. A resistance with minimum value is

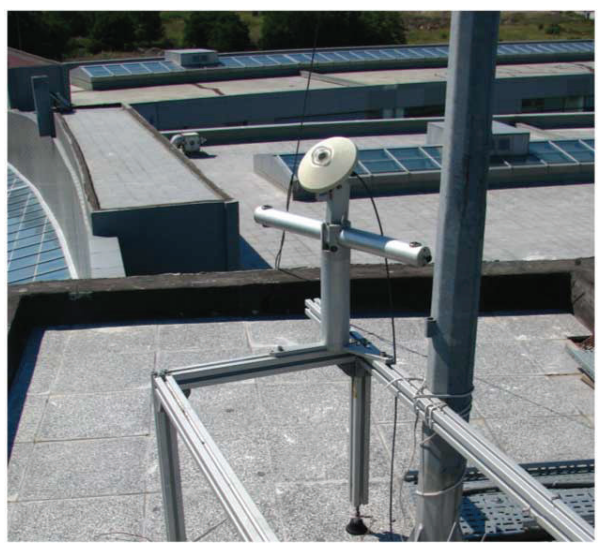

FIGURE 5: Measurement setup of incident global radiation on the platform.

connected in series with loads to measure output currents of PV panels. By the experimental setup, the measured data of the incident global radiation on the surface of PV panels, current and voltage values of PV panels, outdoor temperature, and wind speed data were recorded for 1680 minutes with 15-minute intervals. During the period of measurements, incident global irradiance has changed between $0 \mathrm{~W} / \mathrm{m}^{2}$ and $967.25 \mathrm{~W} / \mathrm{m}^{2}$ and wind speed changed between $0 \mathrm{~m} / \mathrm{s}$ and $5.8 \mathrm{~m} / \mathrm{s}$. Temperature is measured as $28^{\circ} \mathrm{C}$ and $17.1^{\circ} \mathrm{C}$ as the maximum and the minimum values, respectively. 


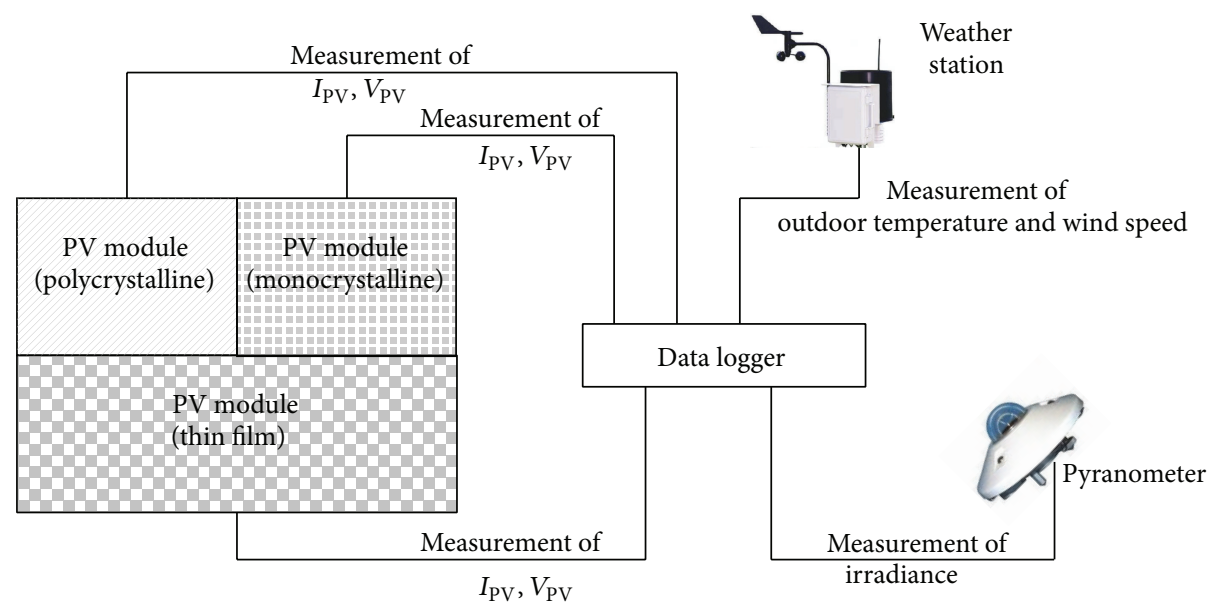

FIGURE 6: Schematic representation of complete measurement setup.

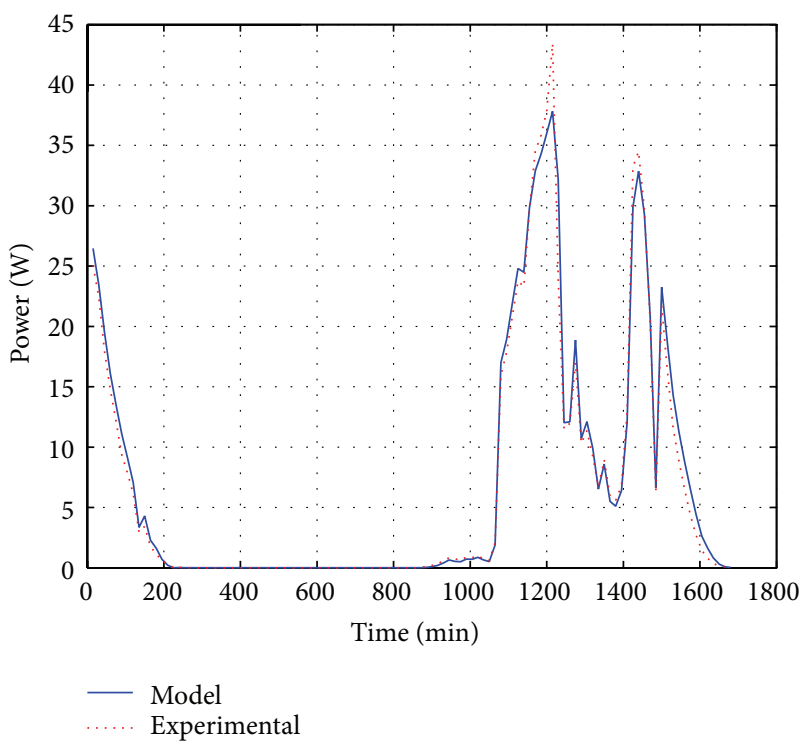

Figure 7: Comparison of the simulation results and monocrystalline silicon panel measurement.

\section{Result and Discussion}

The irradiance, temperature, and wind speed values measured at the actual ambient conditions are used as input parameters in Matlab/Simulink models. Afterward, PV current, voltage, and power values were obtained from models. Simulation results are compared with the measured power values of PV panels under ambient conditions and accuracy of the model is tested. Comparison of the measured power values at different weather conditions from monocrystalline silicon panel output and model output is shown in Figure 7.

The figure depicts that the results from the model mainly overlap the experimental results. It has been calculated numerical evaluation that energy measurements obtained from the model for the measuring period has only $3.25 \%$ deviation from experimental results.

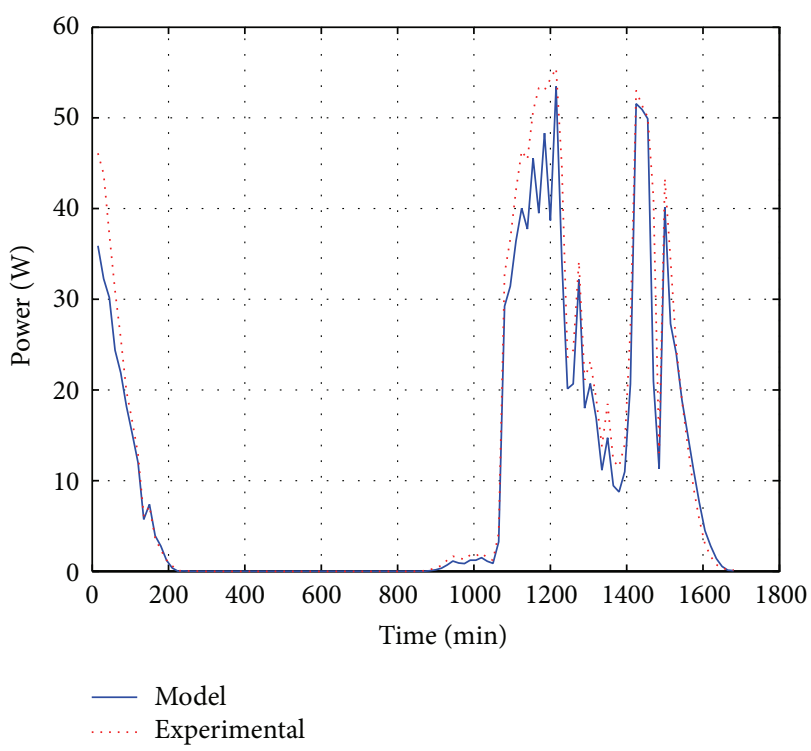

FIGURE 8: Comparison of the simulation results and polycrystalline silicon panel measurement.

Figure 8 illustrates the comparison of model output and the measured power values of polycrystalline silicon technology panel output at different weather conditions.

The measured power values of polycrystalline silicon technology panel output do not show a good correlation with the data of the related model, as in other technologies. Moreover, numerical evaluation showed that there is difference between the energy value obtained from related model and experimental results up to $13.93 \%$. It can be said from this result that suggested model is not very compatible for panels with polycrystalline silicon.

Comparison of measured values and power output of the model related to panels with thin-film technology is given in Figure 9. For thin-film technology, the results obtained from the model are consistent with the experimental results. The numerical evaluation also confirms this with a result of 


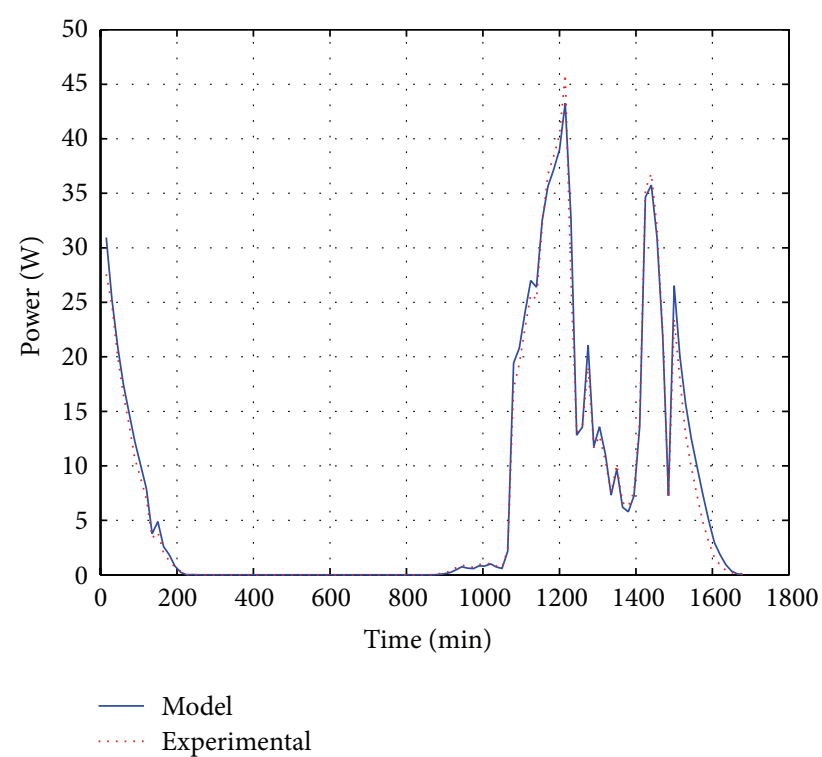

FIGURE 9: Comparison of the simulation results and thin-film panel measurement.

$3.70 \%$ deviation between model output and experimentally measured values under real conditions.

\section{Conclusion}

In this study, a mathematical model of a PV panel is developed considering the irradiance, cell temperature, and wind speed values. This model is tested under a specific resistive load for three different PV panel technologies. Measurements showed that cell temperature and wind speed have significant effect on PV panel output power. The energy output values of three panels are calculated from both measured values under ambient conditions and values of proposed PV model during the measurement period (1680 min). The comparison of the obtained energy values showed that the proposed PV model has a deviation of $3.25 \%$ for monocrystalline silicon PV panels, $3.70 \%$ for thin-film panels, and $13.93 \%$ for polycrystalline silicon panels. The results show that the proposed model gives near real-like results for PV panels having monocrystalline silicon technology and thin-film technology. However, the proposed model could not exhibit a good performance for polycrystalline PV panels.

\section{Nomenclature}

\footnotetext{
$I_{y}: \quad$ PV output current

$V_{y}: \quad$ PV output voltage

$I_{\mathrm{SCS}}$ : Short circuit current at standard test conditions (STC)

$I_{\text {MPS }}$ : Maximum power point current at STC

$V_{\text {OCS }}$ : Open circuit voltage at STC

$V_{\text {MPS }}$ : Maximum power point voltage at STC

$I_{\mathrm{SC}}$ : Short circuit current

$I_{\mathrm{MP}}$ : Maximum power point current
}

$V_{\mathrm{OC}}:$ Open circuit voltage

$V_{\mathrm{MP}}$ : Maximum power point voltage

$G$ : Irradiance

$G_{S}:$ Irradiance at STC $\left(1000 \mathrm{~W} / \mathrm{m}^{2}\right)$

T: $\quad$ Outdoor temperature $\left({ }^{\circ} \mathrm{C}\right)$

$T_{C}$ : Cell temperature $\left({ }^{\circ} \mathrm{C}\right)$

$T_{S}$ : Temperature at STC $\left(25^{\circ} \mathrm{C}\right)$

$w$ : Wind speed $(\mathrm{m} / \mathrm{s})$.

\section{Conflict of Interests}

The authors declare that there is no conflict of interests.

\section{References}

[1] W. Xiao, W. G. Dunford, and A. Capel, "A novel modeling method for photovoltaic cells," in Proceedings of the IEEE 35th Annual Power Electronics Specialists Conference (PESC '04), pp. 1950-1956, Germany, June 2004.

[2] A. Bellini, S. Bifaretti, V. Iacovone, and C. Cornaro, "Simplified model of a photovoltaic module," in Proceedings of the Applied Electronics (AE '09), pp. 47-51, Pilsen, Czech Republic, September 2009 .

[3] P. G. Nikhil and D. Subhakar, "An improved simulation model for photovoltaic cell," in Proceedings of the 2nd Annual Conference on Electrical and Control Engineering (ICECE '11), pp. 19781982, September 2011.

[4] I. H. Altas and A. M. Sharaf, "A photovoltaic array simulation model for matlab-simulink GUI environment," in Proceedings of the International Conference on Clean Electrical Power (ICCEP '07), pp. 341-345, Capri, Italy, May 2007.

[5] S. Nema, R. K. Nema, and G. Agnihotri, "Matlab/simulink based study of photovoltaic cells/modules/array and their experimental verification," International Journal of Energy and Environment, vol. 1, pp. 487-500, 2010.

[6] H. L. Tsai, C. S. Tu, and Y. J. Su, "Development of generalized photovoltaic model using matlab/simulink," in Proceedings of the World Congress on Engineering and Computer Science, pp. 846-851, San Francisco, Calif, USA, 2008.

[7] R. Hernanz, C. Martin, Z. Belver, L. Lesaka, Z. Guerrero, and P. Perez, "Modelling of photovoltaic module," in Proceedings of the International Conference on Renewable Energies and Power Quality, Granada, Spain, 2010.

[8] W. Zhou, H. Yang, and Z. Fang, "A novel model for photovoltaic array performance prediction," Applied Energy, vol. 84, no. 12, pp. 1187-1198, 2007.

[9] J. A. Gow and C. D. Manning, "Development of a photovoltaic array model for use in power-electronics simulation studies," IEE Proceedings: Electric Power Applications, vol. 146, no. 2, pp. 193-200, 1999.

[10] W. de Soto, S. A. Klein, and W. A. Beckman, "Improvement and validation of a model for photovoltaic array performance," Solar Energy, vol. 80, no. 1, pp. 78-88, 2006.

[11] W. Kim and W. Choi, "A novel parameter extraction method for the one-diode solar cell model," Solar Energy, vol. 84, no. 6, pp. 1008-1019, 2010.

[12] D. Sera, R. Teodorescu, and P. Rodriguez, "PV panel model based on datasheet values," in Proceedings of the IEEE International Symposium on Industrial Electronics (ISIE '07), pp. 23922396, Vigo, Spain, June 2007. 
[13] S. Chowdhury, G. A. Taylor, S. P. Chowdhury, A. K. Saha, and Y. H. Song, "Modelling, simulation and performance analysis of a PV array in an embedded environment," in Proceedings of the 42nd International Universities Power Engineering Conference (UPEC '07), pp. 781-785, Brighton, UK, September 2007.

[14] Y. Jiang, J. A. Abu Qahouq, and I. Batarseh, "Improved solar PV cell matlab simulation model and comparison," in Proceedings of the IEEE International Symposium on Circuits and Systems (ISCAS '10), pp. 2770-2773, Paris, France, June 2010.

[15] S. Kalogirou, Solar Energy Engineering: Processes and Systems, chapter 9, Academic Press, New York, NY, USA, 2009.

[16] G. Tamizhmani, L. Ji, Y. Tang, L. Petacci, and C. Osterwald, "Photovoltaic module thermal/wind performance: Long-term monitoring and model development for energy rating," in Proceedings of the NCPV and Solar Program Review Meeting, pp. 936-939, Denver, Colo, USA, 2003. 

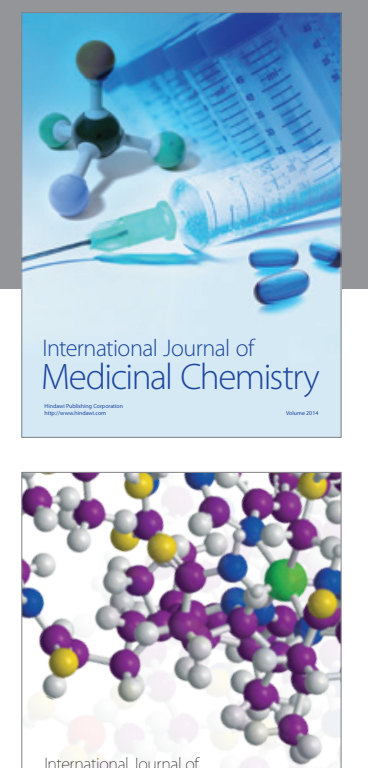

\section{Carbohydrate} Chemistry

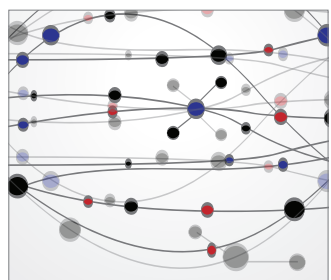

The Scientific World Journal
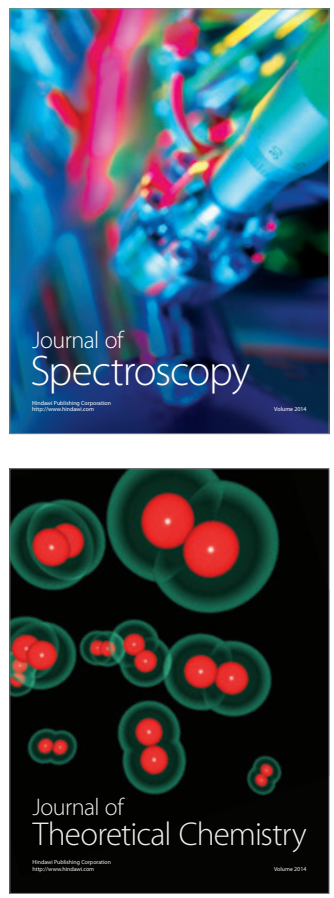
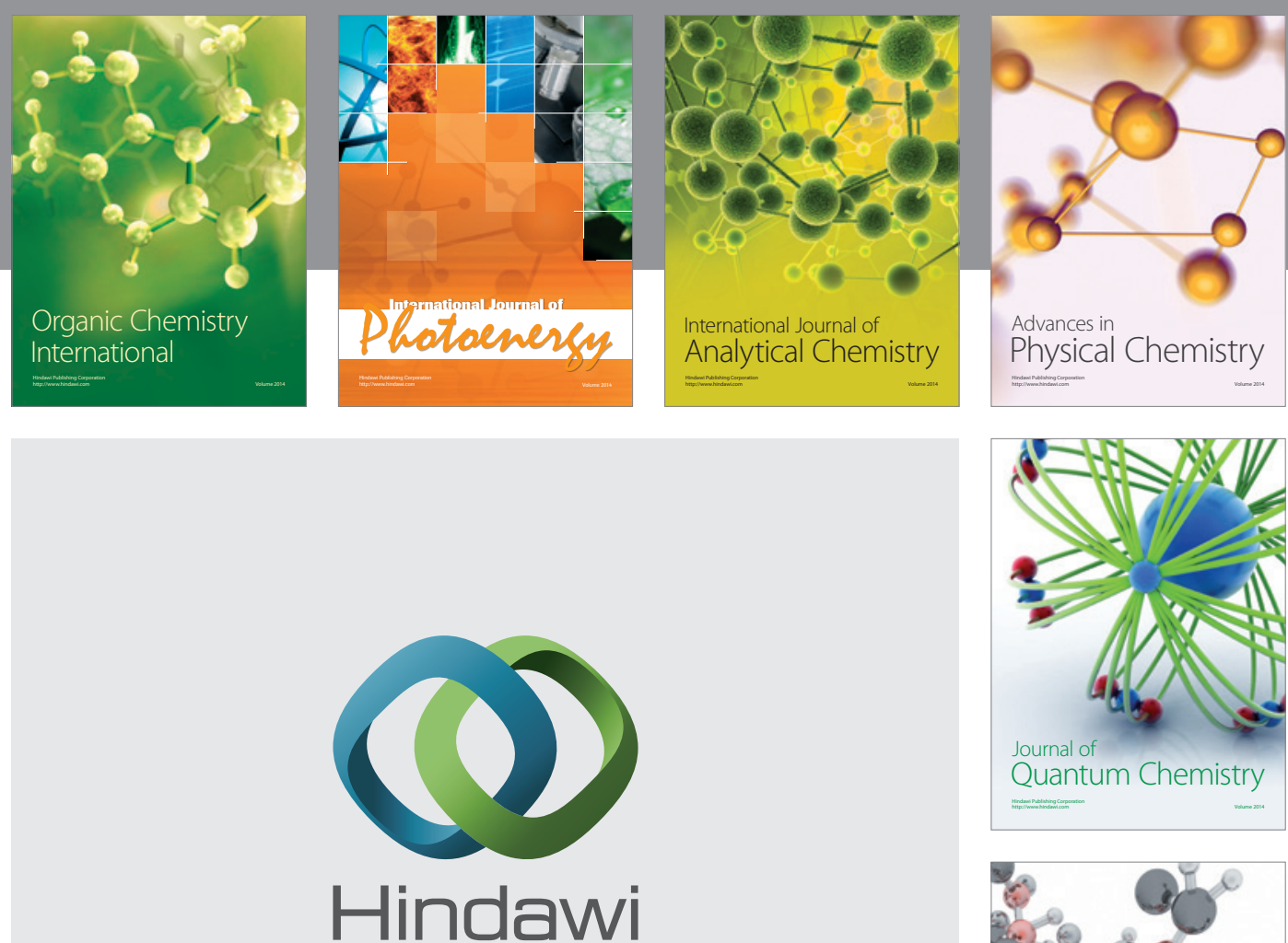

Submit your manuscripts at

http://www.hindawi.com

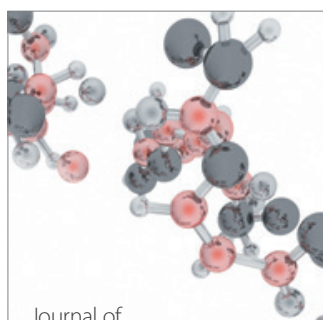

Analytical Methods

in Chemistry

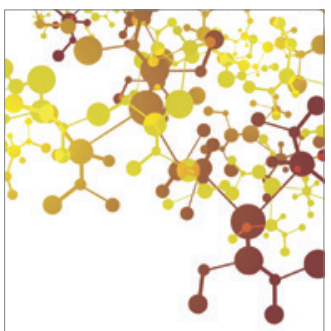

Journal of

Applied Chemistry

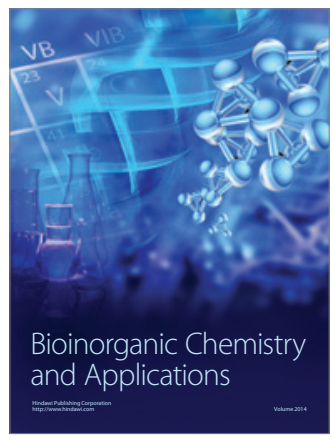

Inorganic Chemistry
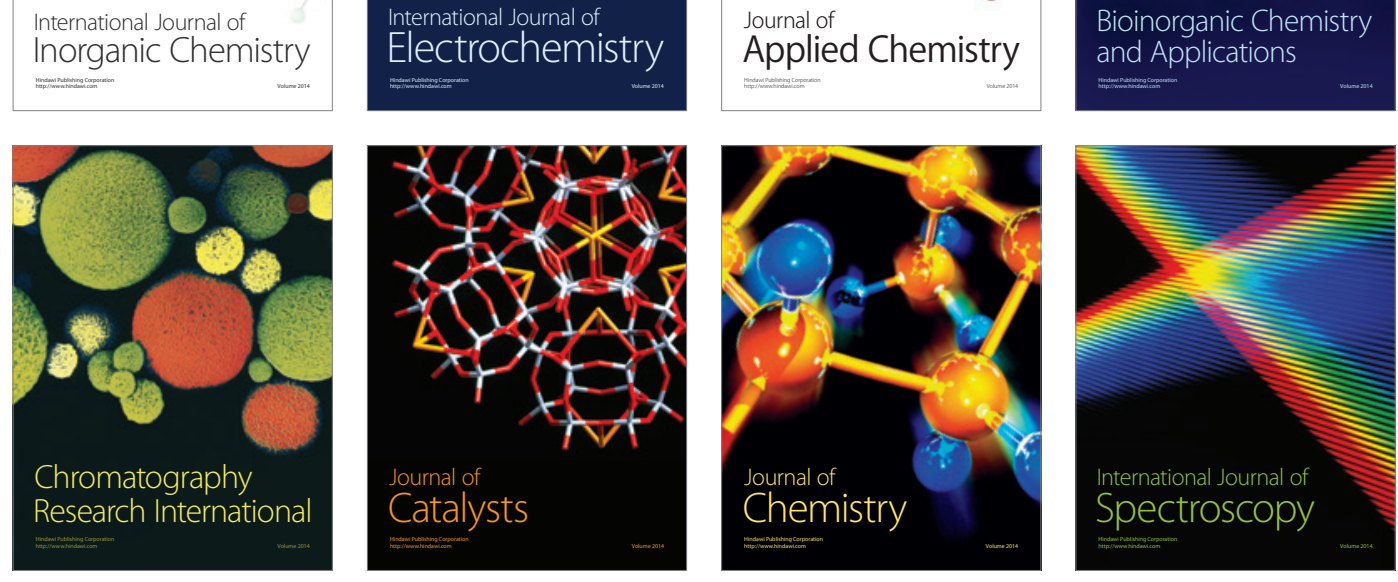